\title{
Optimization of Planting Time and Geometries for Indian Mustard RH-749, under Tarai Conditions of Uttarakhand
}

\author{
Anita Arya* and Anil Shukla
}

Department of Agronomy, G. B. Pant University of Agriculture \& Technology, Pantnagar263145, U. S. Nagar, Uttarakhand, India

*Corresponding author

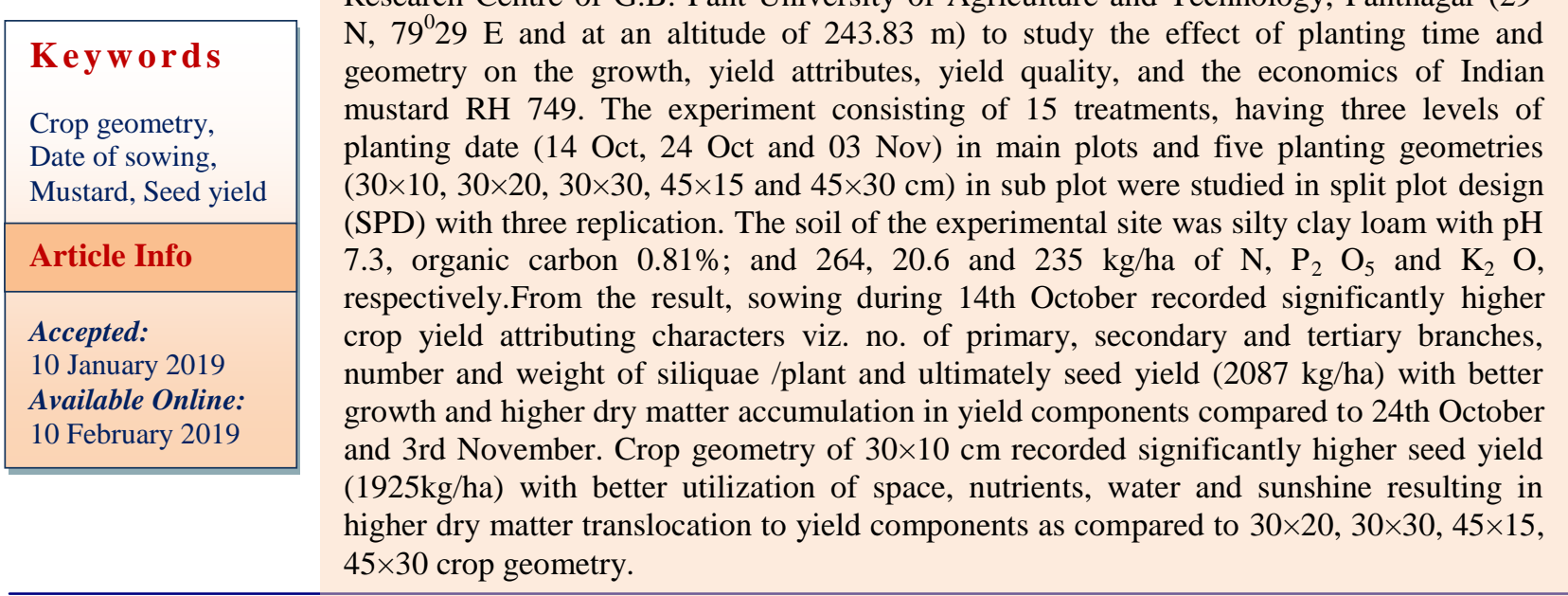

\section{Introduction}

Rapeseed Mustard is a member of the Brassicaceae family and in spite of being one of the most important sources of edible oils rapeseed-mustard is generally grown on marginal lands with poor fertility under rainfed conditions mostly. It is the first in terms of oil production and second most important oilseed crop in India after soybean in terms of seed production, accounts for nearly 20-22 per cent of total oilseeds produced in the country. Mustard seed is grown with a different consumption pattern in the country, Indian mustard is mainly used for extraction of mustard oil while black mustard is mainly used as a condiment (Anonymus, 2015). Among the seven edible oilseeds cultivated in India, rapeseed-mustard contributes 28.6 percent in the total oilseeds production after groundnut sharing 27.8 per cent in the India's oilseed economy. It is 
estimated that $58 \mathrm{mt}$ of oilseeds will be required by the year 2020, wherein the share of Rapeseed- mustard would be around 24.2 mt (Bhartia et al., 2001). The per hectare production of crop is quiet low in the country $(1152 \mathrm{~kg} / \mathrm{ha})$ against the world average of $1400 \mathrm{~kg} / \mathrm{ha}$ in the world (Piri and Sharma, 2006). In Uttarakhand, rapeseed - mustard is the maor oilseed crops during winter season occupying an acerage of 18,079 ha, 43.4 per cent area was in hills and remaining 56.6 percent area in plains. The productivity of rapeseed- mustard in plains and in hills of the state was $1213 \mathrm{~kg} / \mathrm{ha}$ and $568 \mathrm{~kg} / \mathrm{ha}$, respectively (Anonymous, 2017). However, the growth rate of this crop in the state was around 3.3 per cent (Directorate of Economics and Statistics, Department of Agriculture and Cooperation, 2014). Productivity of oilseed Brassicas is largely dependent on the prevailing environmental conditions throughout the life cycle of the crop. It is a thermo sensitive as well as photosensitive crop (Ghosh and Chatterjee, 1988). The production potential of $\mathrm{R} \& \mathrm{M}$ can be fully exploited with suitable agronomic practices and genotypes. Among the different agronomic practices, optimum sowing time plays an important role in fully exploiting the genetic potentiality of a variety as it provides optimum growth conditions such as temperature, light, humidity and rainfall. The growth phase of the crop should synchronize with optimum environmental conditions for better expression of growth and yield. The optimum plant population density/unit area varies with the environment, the genotype, the seeding time and the season. Uniform distribution of crop plants over an area results in efficient use of nutrients, moisture and suppression of weeds leading to high yield (Sonani et al., 2002). Desired plant density obtained when canopy have maximum leaf area to up-taking sunlight at the beginning of reproductive stage. A uniform distribution of plants per unit area is a prerequisite for yield stability (Diepenbrock, 2000). So with the selection of optimum planting time, it is also essential to select suitable plant geometry for obtaining the higher productivity to a great extent.

\section{Materials and Methods}

A field experiment was conducted during the rabi season of 2016-17 at N.E. Borlaug Crop Research Centre of G.B. Pant University of Agriculture and Technology, Pantnagar $\left(29^{0}\right.$ $\mathrm{N}, 79^{0} 29 \mathrm{E}$ and at an altitude of $243.83 \mathrm{~m}$ ). The soil of the experimental site was silty clay loam with $\mathrm{pH} 7.3$, organic carbon $0.81 \%$; and 264, 20.6 and $235 \mathrm{~kg} / \mathrm{ha}$ of $\mathrm{N}, \mathrm{P}_{2} \mathrm{O}_{5}$ and $\mathrm{K}_{2} \mathrm{O}$, respectively. The field experiment was laid out in Split Plot Design with three replications taking three planting dates (October 14, October 24 and November 3) as main plot treatment and five planting geometries $(30 \times 10,30 \times 20,30 \times 30,45 \times 15$ and $45 \times 30 \mathrm{~cm})$ as sub-plot treatment. In totality there were 45 experimental plots of different treatment combinations.

\section{Results and Discussion}

Crop sown on $14^{\text {th }}$ October produced more number of siliquae (324.1) on per plant basis, being significantly superior over $3^{\text {rd }}$ of November (282.2) and did not differ significantly with crop sown on $24^{\text {th }}$ October. Delay in sowing suppressed the reproductive phase leading to an imbalance in the vegetative and reproductive phases of the crop growth and development. This resulted in poor source to sink ratio, which is evident from the reduction in various yield attribute like number of siliquae. Singh et al., (2001) also reported that a delay in planting influenced the number of siliquae. Whereas, among the various planting geometries, the wider geometries resulted into more number of siliquae per plant. $45 \times 30 \mathrm{~cm}$ produced the highest number of siliquae (336.0) per plant 
which was significantly superior over that other planting geometry. The geometry of $30 \times 30 \mathrm{~cm}$ had also produced more number of siliquae per plant (311.2), second to the $45 \times 30 \mathrm{~cm}$ geometry. These results were in conformity with that of Kumari et al., (2012).The crop sown on $14^{\text {th }}$ October recorded higher number of seeds per siliqua (15.5) obtained from different branches which is significantly superior over $24^{\text {th }}$ October and $3^{\text {rd }}$ November sown crops. Crop sown on $3^{\text {rd }}$ November resulted into the lowest number of seeds per siliqua (11.7) which was because of slower growth of the crop than that of crop sown on $14^{\text {th }}$ October. Similar findings have also been reported by Rabiee et al., (2004). Among the various planting geometries, $45 \times 30 \mathrm{~cm}$ produced 15.3 seeds in a siliqua which showed its supremacy over the other geometries. $30 \times 10 \mathrm{~cm}$ produced significantly lower number of seeds per siliqua (12). This increase in the number of seeds per siliqua with the wider geometries has also been reported by Kumari et al., (2012).

The maximum weight and seed weight per plant was recorded in October 14 sown crop being significantly superior over the third sowing and at par with second sowing. In first sown crop the longer reproductive phase had a positive influence on seed development that increased the seed weight and finally the seed yield. Similar findings have also been reported by Saha et al., (2003) in Indian mustard (Brassica juncea). The seed weight per plant was significantly higher in $45 \times 30$ $\mathrm{cm}$ plant geometry which was significantly superior over other plant geometry and at par with $30 \times 30 \mathrm{~cm}$ spacing. The seed weight per plant was maximum in wider spacing because of more space available for growth and development resulted in higher seed yield. Similar findings have also been reported by Gupta and Saini (1988) (Table 1).

Table.1 Effect of planting date and plant geometries on yield parameters of Indian mustard RH-749

\begin{tabular}{|c|c|c|c|c|c|}
\hline \multirow{2}{*}{$\begin{array}{l}\text { Treatment } \\
\text { Planting date }\end{array}$} & \multicolumn{5}{|c|}{ Yield character } \\
\hline & $\begin{array}{l}\text { Siliqua } \\
\text { /plant }\end{array}$ & $\begin{array}{l}\text { Seeds / } \\
\text { siliqua }\end{array}$ & $\begin{array}{l}1000 \text { seed } \\
\text { weight }(g)\end{array}$ & $\begin{array}{l}\text { Seed } \\
\text { weight } \\
\text { /plant (g) }\end{array}$ & $\begin{array}{l}\text { Seed } \\
\text { yield(kg/ha) }\end{array}$ \\
\hline 14 October & 324.1 & 15.5 & 4.67 & 86.5 & 2087 \\
\hline 24 October & 303.0 & 13.5 & 4.03 & 81.3 & 1809 \\
\hline 03 November & 282.2 & 11.7 & 3.38 & 71.3 & 1374 \\
\hline SEm \pm & 8.0 & 0.5 & 0.07 & 1.7 & 49 \\
\hline $\mathrm{CD}(\mathrm{P}=\mathbf{0 . 0 5})$ & 31.3 & 1.7 & 0.25 & 6.5 & 193 \\
\hline \multicolumn{6}{|c|}{ Planting geometries (cm) } \\
\hline $30 \times 10$ & 276.5 & 12.0 & 3.37 & 73.9 & 1925 \\
\hline $30 \times 20$ & 291.3 & 12.6 & 3.50 & 76.3 & 1857 \\
\hline $30 \times 30$ & 311.2 & 14.3 & 4.45 & 82.8 & 1742 \\
\hline $45 \times 15$ & 300.1 & 13.4 & 4.07 & 79.7 & 1674 \\
\hline $45 \times 30$ & 336.0 & 15.3 & 4.77 & 85.8 & 1586 \\
\hline SEm \pm & 10.1 & 0.3 & 0.12 & 2.0 & 43 \\
\hline $\mathrm{CD}(\mathrm{P}=0.05)$ & 29.5 & 0.9 & 0.35 & 5.9 & 126 \\
\hline
\end{tabular}

The seed yield of Indian mustard RH 749, decreased significantly with delay in sowing date from $14^{\text {th }}$ October to $3^{\text {rd }}$ November, showing the highest yield $2087 \mathrm{~kg} / \mathrm{ha}$ for $14^{\text {th }}$ 
October which was significantly superior over other two planting date and lowest yield 1374 $\mathrm{kg} / \mathrm{ha}$ for $3^{\text {rd }}$ November. The maximum seed yield recorded in first sowing as compared to delay sowing.it might be due to the fact that the early sown crop got longer time period to utilize available resources and favourable temperature at later growth stages while shorter time available for the late sown crop to utilize available growth factors (light, nutrients, moisture etc.) responsible for lower LAI and poor plant growth which results poor dry matter accumulation for the production and partitioning of assimilates to sink for better vegetative growth, leading to a decline of yield and yield contributing components than the timely sown crop. Similar findings indicating the decrease in seed yield with delayed sowing have also reported by Shargi et al., (2011). Among the various planting geometries the $30 \times 10 \mathrm{~cm}$ spacing yielded the $1925 \mathrm{~kg} / \mathrm{ha}$ maximum being significantly superior over rest of the plant geometries except $30 \times 20 \mathrm{~cm}$ which did not differ significantly with $30 \times 10 \mathrm{~cm}$. Closer plant spacing recorded significantly higher seed yield as compared to wider plant geometry of $45 \times 30 \mathrm{~cm}(1586 \mathrm{~kg} / \mathrm{ha})$. Wider spacing could not fully utilized the available soil nutrients, moisture and light consequently reducing the seed yield Similar findings on planting geometry have been reported by Chaniyara et al., (2002).

With the results obtained during the course of investigation it could be concluded that the timely sowing of Indian mustard RH 749 shall be performed in $30 \mathrm{~cm} \times 30 \mathrm{~cm}$ or $30 \mathrm{~cm} \times 20$ $\mathrm{cm}$ planting geometry but in case the sowing gets delayed somehow, the loss in seed yield could be compensated planting the crop in narrow geometry under tarai region of Uttarakhand.

\section{References}

Anonymus, 2015.Mustard seed survey report.
Religareonline.com/research / Disclamer_rcl.html.

Anonymous, 2017. Annual Report of Government of Uttarakhand.

Bhartia, A.M., Shukla, A.K., Kaushik, C.D., Kumar, P.R. and Singh, N.B. 2001. Major diseases of Rapeseed-mustard and their management. NRC on Rapeseed-Mustard, ICAR, Sewer, Bharatpur (Rajasthan). 65(3): 580581.

Chaniyara, N. J., Solanki, R. M. and Bhalu, V. B. 2002.Effect of inter and intra row spacing on yield of mustard. Agricultural Science Digest. 22(1): 48-50.

Diepenbrock, W. 2000. Yield analysis of winter oilseed rape (Brassica napus L.): a review, Field Crops Research, 67: 35-49.

Directorate of Economics and Statistics, 2016-17. Department of Agriculture and Cooperation (DAC).

Ghosh, R. K. and Chatterjee, B.N. 1988. Effect of dates of sowing on oil content and fatty acid profiles of Indian mustard. Journal of Oilseeds Research. 5(2): 144-149.

Gupta, J. R. And Saini, J. S. 1988. Response of rabisarson (B. napus) to nitrogen and row spacing. Indian Journal of Agronomy.33(3): 242-243.

Kumari, A., Singh, R. P. and Yeshpal. 2012. Productivity, nutrient uptake and economics of mustard hybrid (Brassica juncea) under different planting time and row spacing. Indian Journal of Agronomy. 57(1): 61-67.

Rabiee, M., Karimi, M. M. and Safa, F. 2004. Effect of planting dates on grain yield and agronomical characters of rapeseed cultivars as a second crop after rice. Iranian Journal of Agricultural Science. 35(1): 177-187.

Saha, C. S., Baral, K., Garai, A. K. and Dutta, J.K. 2003. Effect of sowing dates and 
nitrogen levels on some biochemical parameters, seed yield and oil content in rapeseed. Journal of Maharahtra Agricultural University. 28(3): 235237.

Shargi, Younes., Rad, A. H. S., Band, A. A., Noor mohammadi, G. and Zahedi, H. 2011. Yield and yield components of six canola (Brassica napus L.) cultivars affected by planting date and water deficit stress. African Journal of Biotechnology. 10(46): 9309-9313.
Singh, R., Patidar, M. and Singh, B. 2001. Response of Indian mustard cultivars to different sowing time. Indian Journal of Agronomy. 43(4): 709-712. Sonani, V. V., Patel, P. T. and Patel G. G. 2002.Performance of mustard under different dates of sowing in Bhal and Coastal Agro-climatic zone of Gujarat. Journal of Oilseeds Research. 19(1): 122.

\section{How to cite this article:}

Anita Arya and Anil Shukla. 2019. Optimization of Planting Time and Geometries for Indian Mustard RH-749, under Tarai Conditions of Uttarakhand. Int.J.Curr.Microbiol.App.Sci. 8(02): 1040-1044. doi: https://doi.org/10.20546/ijcmas.2019.802.122 